\title{
RESPONSE OF COTTON TO NITROGEN FERTILIZER AND SPACING
} BETWEEN HOLES

${ }^{1}$ M. O. Alubaidi

Prof.
${ }^{2}$ M. A. Al-Naqeeb

Prof.
${ }^{3}$ H. K. Saleh*

Lecturer

${ }^{1,3}$ Dept. of Field Crop - Coll. of Agric. - Anbar Univ.

${ }^{2}$ Dept. of Field Crops - Coll. of Agric. - Univ. of Baghdad

mohammadalubaidi@yahoo.com

\section{ABSTRACT}

This experiment was conducted at the farm of field crop department, College of Agriculture, University of Baghdad during two summer seasons (2010 and 2011) in order to know the response of cotton var. Lashata to nitrogen levels and spacing between holes. A randomized complete block design under arrangement of split plot with four replications was used. The plant spacing; 10,20 and $30 \mathrm{~cm}$ between holes and $75 \mathrm{~cm}$ between rows considered as main plots, while three nitrogen levels (150, 200 and $250 \mathrm{Kg} \mathrm{N} \mathrm{ha}^{-1}$ ) are considered as sub plots. The results showed that using $10 \mathrm{~cm}$ between hills were significantly superior in boll weight $\left(3.69\right.$ and 4.26) gm.boll $^{-1}$, seed cotton yield (3.03 and 3.6) t.ha $^{-1}$ and lint yield (1.13 and 1.30) t.ha $^{-1}$ in both seasons 2010 and 2011 respectively. While, $30 \mathrm{~cm}$ spacing significantly superior in number of open bolls $\left(12.10\right.$ and 13.6) bolls.plant ${ }^{-1}$ and ginning percentage (39.05 and 37.44)\% in both seasons respectively. The nitrogen fertilizer $250 \mathrm{~kg} \mathrm{~N} \mathrm{ha}^{-1}$ was significantly superior in dehiscence bolls number, seed cotton yield, lint yield and ginning percentage in both seasons 2010 and 2011 respectively. It can be concluded that 'using $10 \mathrm{~cm}$ spacing between holes with $250 \mathrm{~kg} \mathrm{~N} \mathrm{ha}{ }^{-1}$ to achieve highest seed cotton yield.

Keywords: cotton, nitrogen, planting spacing, lint yield, ginning percentage.

* Part of Ph.D. Dissertation of third author.

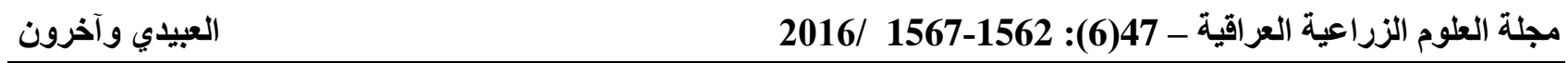

استجابة القطن لمستويات من السماد النتروجيني والمسافة بين الجور
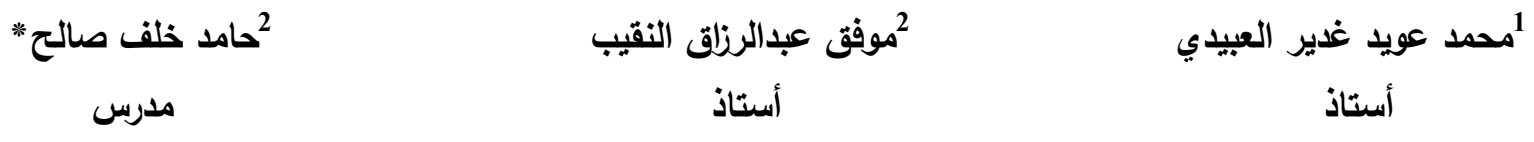

$$
\text { 12ققسم المحاصيل الحقلية - كلية الزراعة - جامعة الانبار }
$$

mohammadalubaidi@yahoo.com

\author{
المستخلص
}

طبقت التجرية في حقل تجارب قسم المحاصيل الحقلية-كلية الزراعة-جامعة بذاد-ابو غريب خلال الموسم الصيفي لعامي 2010 و 2011 بهدف معرفة استجابة القطن صنف لاثاتا لمستويات النتروجين والمسافة بين الجور. استعمل تصميم القطاعات الكاملة المعثاة بترتيب الالواح المنثقة بأربعة مكررات. كانت المسافة بين الجور داخل المرز الواحد 10 و20 و 30 سم مع مسافة 75 سم بمدئة بين المروز

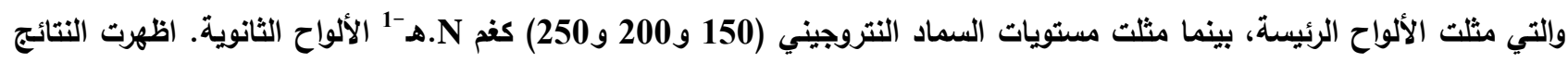

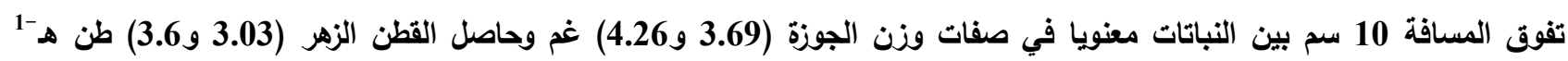

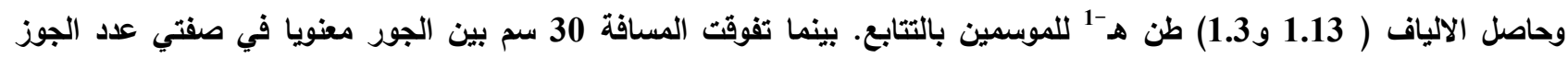
المتفتح ونسبة تصافي الحلج وللموسمين بالتتابع. كما اظهرت النتائج تفوق مستوى التسميد 250 كفم N.هـ وحاصل القطن الزهر وحاصل الالياف ونسبة تصافي الحلج للموسمين بالتتابع. لذلك نوصي بالزراعة على مسافة 10 سم بين الجور

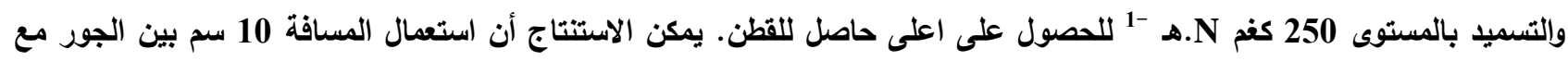

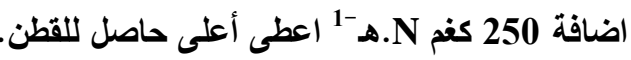




\section{INTRODUCTION}

Cotton Gossypium hirsutum L. is one of the most important industrial crops, which is planted in order to obtain fiber and oil. The productivity per unit area in Iraq is still low due to insufficient management. Cotton crop is stressful of soil, as it consumes high amounts of nutrients in order to deepen the roots and enlarge of total vegetative growth. Nitrogen is one of the most important of these elements, while the cotton plants need from the beginning of the growth stage to increase plant growth shoots and strengthen the root system, which is necessary for rate, growth, flowering and maturation $(2,4)$. The availability of nitrogen in the soil will be a limiting factor for cotton production when increasing of plant density. The planting method and distribution of plants in the field are the most important factors affecting the growth and yield of cotton (13). Studies refers that the cotton plants during the stage progresses increases the absorption of nitrogen until they reached their highest after four months from planting and then begging to decrease. Reduced nitrogen with high plant density causes configuration of weak stem and low production. Yellowing of leaves and plant dwarfing are one of the most common symptoms nitrogen deficiencies (5, 17). This research was carried out to investigate the effect of nitrogen fertilizer and plant spacing on cotton yield and its quality.

\section{MATERIALS AND METHODS}

This study was carried out during 2010 and 2011 at the field of the College Agriculture University of Baghdad, in a soil with salt clay loam texture, using RCBD design with split plot arrangement and four replicates. Three nitrogen levels (150, 200 and 250) Kg N.ha ${ }^{-1}$ considered as a sub-plots, while, the hill spacing (10, 20 and 30) $\mathrm{cm}$ between hills and $75 \mathrm{~cm}$ between rows, which represented plant density $133333.33,66666.66$ and 44444.44 plant.ha $^{-1}$ respectively as main plots. The experimental unit area was $3 \times 3.75 \mathrm{~m}$, Lashata variety was used. Sowing date was at the beginning of April in each year, using 3-4 seeds in each hill with 3-5 cm depth. Phosphorus added as a $\mathrm{P}_{2} \mathrm{O}_{5}$ at a rate of 100 $\mathrm{Kg} \mathrm{ha}^{-1}$, either nitrogen added as a urea (46\% $\mathrm{N})$ in two times, the first after emergence and the second after 45 days from the first time. Ten plants were selected randomly from each experimental unit to study the following traits:: 1. Number of open bolls.plant ${ }^{-1}$.

2. Boll weight (gm).

3. Seed cotton yield $\left(\mathrm{Kg}_{\mathrm{h}} \mathrm{ha}^{-1}\right)$.

4. Lint yield $\left(\mathrm{Kg} \cdot \mathrm{ha}^{-1}\right)$.

5. Ginning percentage $\%$ : using the equation

Ginning percentage $(\%)=$ Lint weight $(\mathrm{gm}) /$

$\{$ Lint weight $(\mathbf{g m})+$ seeds weight $(\mathbf{g m})\} \times 100$

Data were analyzed as analysis of variance using a statistical analysis program Genstat, while the means were compared using LSD 0.05 .

\section{RESULTS AND DISCUSSION Number of open bolls.plant ${ }^{-1}$}

Table 1 indicates the superiority of $30 \mathrm{~cm}$ plant spacing which achieve the highest $(12.10$ and 13.60 bolls plant ${ }^{-1}$ ), while the $10 \mathrm{~cm}$ spacing gave the lowest ( 7.12 and 7.99 bolls. plant $^{-1}$ ) for both years respectively. The reason may be that the plants which cultivated in narrow spacing $(10 \mathrm{~cm})$ had highly competition for growth factors in addition to shading $(17,18)$. The results in Table 1 represent that $250 \mathrm{Kg} \mathrm{N} \cdot \mathrm{ha}^{-1}$ level achieve the highest rate for this characters (11.19 and 12.07) boll.plant ${ }^{-1}$, while the $150 \mathrm{Kg} \mathrm{N} \cdot \mathrm{ha}^{-1}$ level produced a lower rate (8.38 and 9.97) boll.plant ${ }^{-1}$ for both years respectively. These results deals that the cotton plants had good response to the $\mathrm{N}$ element, which played an important role in the improving of the source size and increasing the rate of net photosynthesis (6). A significant the inter-action between plant spacing and $\mathrm{N}$ levels was revealed, the $30 \mathrm{~cm}$ spacing with $250 \mathrm{Kg}$ N.ha $^{-}$ ${ }^{1}$ recorded the highest value (13.43 and 14.25) boll.plant ${ }^{-1}$, while treatment $10 \mathrm{~cm}$ with 150 Kg N.ha ${ }^{-1}$ gave the lowest rate (5.12 and 6.26) boll.plant ${ }^{-1}$ for the two years respectively. This 
this results revealed that the response of number of open bolls plant ${ }^{-1}$ were different significantly from nitrogen.

\section{Boll weight}

Table 2 shows the significant influence of plant spacing on boll weight for 2011 season only, the spacing $10 \mathrm{~cm}$ produced highest weight 4.26 gm.boll ${ }^{-1}$ while the lowest 3.36 gm.boll ${ }^{-1}$ for the spacing $30 \mathrm{~cm}$. That's may be due to the compensation principle between yield components, it is found that the plant, which increased the number of dehiscence bolls was in wide distance between plants (Table 1), that's indicated by the results of Ali et al (3) and Clawson et al (8).

\section{Seed cotton yield}

According to Table 3 results indicate that was significant difference between plant spacing on seed cotton yield, a spacing $10 \mathrm{~cm}$ has produced highest yield (3028.0 and 3551.4) $\mathrm{Kg}_{\mathrm{haa}}{ }^{-1}$, while the spacing $30 \mathrm{~cm}$ produced the lowest (1914.2 and 2353.8) Kg.ha ${ }^{-1}$ for both years, respectively (Table3). That's may be due to the increase of the number of plants in unit area in the $10 \mathrm{~cm}$ spacing in addition to a significant increase of boll weight (Table 2) that is confirmed by the results of Ali et al (3) and Akhtar et al (1). Significant difference, also found among $\mathrm{N}$ levels on cotton yield, where the $250 \mathrm{Kg} \mathrm{N} . \mathrm{ha}^{-1}$ produced the highest 2817.0 and 3153.4 Kg.ha ${ }^{-1}$ and $150 \mathrm{Kg} \mathrm{N} . \mathrm{ha}^{-1}$, produced lowest 2138.6 and $2776.9 \mathrm{Kg} \cdot \mathrm{ha}^{-1}$ for both years, respectively. That's may be due to the plants under treatment $250 \mathrm{Kg} \mathrm{N}$. ha ${ }^{-1}$ had the highest rate of open boll.plant ${ }^{-1}$ (Table 1) in addition to the heavy boll weight (Table 2). These results agreed with what achieved by Rashidi and Gholami (19); Ibrahim et al (14) and Khan and Dar (15). A significant interaction was found between planting spacing and $\mathrm{N}$ levels, the $10 \mathrm{~cm}$ spacing with $250 \mathrm{Kg} \mathrm{N} . \mathrm{ha}^{-1}$ gave the highest yield (3732.3 and 3821.3) Kg.ha ${ }^{-1}$ and a lower yield between $30 \mathrm{~cm}$ with $150 \mathrm{Kg} \mathrm{N} . \mathrm{ha}^{-1}$ (1735.2 and 2223.7) $\mathrm{Kg}_{\mathrm{Ha}}{ }^{-1}$ for both years respectively. This interaction was due to difference in response to the spacing plant and nitrogen fertilizer.

\section{Lint yield}

Table 4 shows significant difference between plant spacing was revealed in lint yield for both years. The highest was 1135.4 and 1285.5 $\mathrm{Kg} \mathrm{ha}^{-1}$ for $10 \mathrm{~cm}$ spacing between hill, while the $30 \mathrm{~cm}$ produced the lower reached 735.9 and $881.6 \mathrm{Kg}$. $\mathrm{ha}^{-1}$ for the two years, respectively, that is supports by Boquet (7), Akhtar et al (1) and Demastro (9). Also, a significant difference were revealed between $\mathrm{N}$ fertilizer in lint yield (Table 4), The highest yield was 1078.0 and $1185.6 \mathrm{Kg}$. $\mathrm{ha}^{-1}$ for 250 $\mathrm{Kg} \mathrm{N}$. ha ${ }^{-1}$, while, the lowest 800.8 and 999.6 $\mathrm{Kg}$. ha ${ }^{-1}$ for $150 \mathrm{Kg} \mathrm{N}$. ha ${ }^{-1}$ for the two years, respectively. This may be due to the $\mathrm{N}$, which increased the total cotton yield (Table 3), (14, 16). A significant interaction between $\mathrm{N}$ levels and plant spacing was obtained in the lint yield. The level $250 \mathrm{Kg} \mathrm{N} . \mathrm{ha}^{-1}$ with $10 \mathrm{~cm}$ spacing produced highest 1418.4 and 1423.0 $\mathrm{Kg} \mathrm{ha}^{-1}$, while the level $150 \mathrm{Kg} \mathrm{N} . \mathrm{ha}^{-1}$ with 30 $\mathrm{cm}$ the lowest produced (664.3 and 825.1) $\mathrm{Kg} \cdot \mathrm{ha}^{-1}$ for two years respectively.

\section{Ginning percentage}

Table 5 shows significant difference among $\mathrm{N}$ levels and plant spacing in ginning percentage. The spacing $30 \mathrm{~cm}$ between hills had significantly superior to other ginning\% highest ginning\% that reached 39.05 and $37.44 \%$, while $10 \mathrm{~cm}$ produced the lowest percentage ( 37.73 and 36.67$) \%$ for both years respectively. This could be due to the lack of competition at the growth factors between plant, which are planted in wider spacing and provided more cellulose in secondary wall of lint $(10,11,18)$. As for $\mathrm{N}$ levels, the highest ginning percentage was 38.97 and $37.44 \%$ produced from $250 \mathrm{Kg} \mathrm{N} . \mathrm{ha}^{-1}$ while $150 \mathrm{Kg} \mathrm{N}$. $\mathrm{ha}^{-1}$ produced the lowest 37.52 and $36.69 \%$ for both years respectively. This may be due to the fact that $\mathrm{N}$ increasing photosynthesis and provide more carbohydrates which are deposited in the secondary wall and formation of cellulose, which increase lint weight $(12,20)$. 
Table 1. Effect of spacing between hills and nitrogen levels on number of open bolls.plant ${ }^{-1}$ in years 2010 and 2011

\begin{tabular}{|c|c|c|c|c|c|c|c|c|}
\hline \multicolumn{5}{|c|}{2010} & \multicolumn{4}{|c|}{2011} \\
\hline \multirow{2}{*}{$\begin{array}{l}\text { Spacing } \\
\text { between hill } \\
(\mathbf{c m})\end{array}$} & \multicolumn{4}{|c|}{ Nitrogen levels (Kg N.ha $\left.{ }^{-1}\right)$} & \multicolumn{4}{|c|}{ Nitrogen levels (Kg N.ha $\left.{ }^{-1}\right)$} \\
\hline & 150 & 200 & 250 & Mean & 150 & 200 & 250 & Mean \\
\hline 10 & 5.12 & 7.55 & 8.68 & 7.12 & 6.76 & 8.26 & 8.97 & 7.99 \\
\hline 20 & 9.53 & 10.80 & 11.47 & 10.60 & 10.34 & 11.63 & 12.99 & 11.65 \\
\hline 30 & 10.48 & 12.40 & 13.43 & 12.10 & 12.81 & 13.74 & 14.25 & 13.60 \\
\hline LSD 0.05 & 0.71 & & & 0.48 & 0.57 & & & 0.40 \\
\hline Mean & 8.38 & 10.25 & 11.19 & & 9.97 & 11.21 & 12.07 & \\
\hline LSD 0.05 & 0.41 & & & & 0.33 & & & \\
\hline
\end{tabular}

Table 2. Effect of spacing between hills and nitrogen levels on boll weight $\left(\mathrm{gm.boll}^{-1}\right)$ in years 2010 and 2011

\begin{tabular}{|c|c|c|c|c|c|c|c|c|}
\hline \multicolumn{5}{|c|}{2010} & \multicolumn{4}{|c|}{2011} \\
\hline \multirow{2}{*}{$\begin{array}{l}\text { Spacing } \\
\text { between hill } \\
\text { (cm) }\end{array}$} & \multicolumn{4}{|c|}{ Nitrogen levels $\left(\mathrm{Kg} \mathrm{N} \cdot \mathrm{ha}^{-1}\right)$} & \multicolumn{4}{|c|}{ Nitrogen levels (Kg N.ha' $\left.{ }^{-1}\right)$} \\
\hline & 150 & 200 & 250 & Mean & 150 & 200 & 250 & Mean \\
\hline 10 & 3.81 & 3.61 & 3.65 & 3.69 & 4.33 & 4.26 & 4.20 & 4.26 \\
\hline 20 & 3.76 & 3.51 & 3.33 & 3.53 & 4.18 & 3.84 & 3.60 & 4.89 \\
\hline 30 & 3.77 & 3.11 & 3.19 & 3.36 & 3.74 & 3.52 & 3.43 & 3.56 \\
\hline LSD 0.05 & N.S & & & N.S & N.S & & & 0.54 \\
\hline Mean & 3.78 & 3.41 & 3.39 & & 4.08 & 3.89 & 3.74 & \\
\hline LSD 0.05 & N.S & & & & N.S & & & \\
\hline
\end{tabular}

Table 3. Effect of spacing between hills and nitrogen levels on seed cotton yield (Kg. $\left.\mathrm{ha}^{-1}\right)$ in years 2010 and 2011

\begin{tabular}{|c|c|c|c|c|c|c|c|c|}
\hline \multicolumn{5}{|c|}{2010} & \multicolumn{4}{|c|}{2011} \\
\hline \multirow{2}{*}{$\begin{array}{l}\text { Spacing } \\
\text { between hill } \\
\text { (cm) }\end{array}$} & \multicolumn{4}{|c|}{ Nitrogen levels (Kg N.ha ${ }^{-1}$ ) } & \multicolumn{4}{|c|}{ Nitrogen levels (Kg N.ha ${ }^{-1}$ ) } \\
\hline & 150 & 200 & 250 & Mean & 150 & 200 & 250 & Mean \\
\hline 10 & 2249.4 & 3102.3 & 3732.3 & 3028.0 & 3241.4 & 3591.5 & 3821.4 & 3551.4 \\
\hline 20 & 2431.2 & 2587.7 & 2643.3 & 2554.1 & 2865.7 & 3010.0 & 3164.4 & 3013.4 \\
\hline 30 & 1735.2 & 1932.1 & 2075.3 & 1914.2 & 2223.7 & 2363.2 & 2474.5 & 2353.8 \\
\hline LSD 0.05 & 72.4 & & & 44.6 & 88.7 & & & 54.7 \\
\hline Mean & 2138.6 & 2540.7 & 2817.0 & & 2776.9 & 2988.2 & 3153.4 & \\
\hline LSD 0.05 & 44.5 & & & & 54.6 & & & \\
\hline
\end{tabular}

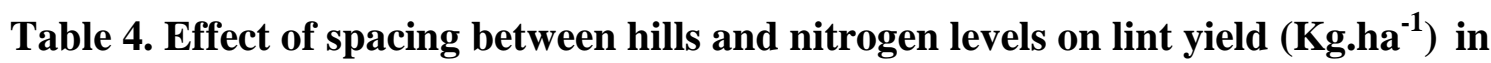
years 2010 and 2011

\begin{tabular}{|c|c|c|c|c|c|c|c|c|}
\hline \multicolumn{5}{|c|}{2010} & \multicolumn{4}{|c|}{2011} \\
\hline \multirow{2}{*}{$\begin{array}{l}\text { Spacing } \\
\text { between hill } \\
(\mathrm{cm})\end{array}$} & \multicolumn{4}{|c|}{ Nitrogen levels (Kg N.ha $\left.{ }^{-1}\right)$} & \multicolumn{4}{|c|}{ Nitrogen levels (Kg N.ha $\left.{ }^{-1}\right)$} \\
\hline & 150 & 200 & 250 & Mean & 150 & 200 & 250 & Mean \\
\hline 10 & 826.5 & 1161.4 & 1418.4 & 1135.4 & 1117.2 & 1316.3 & 1423.0 & 1285.5 \\
\hline 20 & 911.7 & 982.1 & 1014.5 & 969.5 & 1056.6 & 1113.7 & 1193.6 & 1121.3 \\
\hline 30 & 664.3 & 742.3 & 801.1 & 735.9 & 825.1 & 879.7 & 940.1 & 881.6 \\
\hline LSD 0.05 & 54.1 & & & 33.1 & 59.4 & & & 36.3 \\
\hline Mean & 800.8 & 961.9 & 1078.0 & & 999.6 & 1103.2 & 1185.6 & \\
\hline LSD 0.05 & 33.3 & & & & 36.6 & & & \\
\hline
\end{tabular}


Table 5. Effect of spacing between hills and nitrogen levels on ginning percentage (\%) in years 2010 and 2011

\begin{tabular}{|c|c|c|c|c|c|c|c|c|}
\hline \multicolumn{5}{|c|}{2010} & \multicolumn{4}{|c|}{2011} \\
\hline \multirow{2}{*}{$\begin{array}{l}\text { Spacing } \\
\text { between hill } \\
\text { (cm) }\end{array}$} & \multicolumn{4}{|c|}{ Nitrogen levels (Kg N.ha $\left.{ }^{-1}\right)$} & \multicolumn{4}{|c|}{ Nitrogen levels (Kg N.ha $\left.{ }^{-1}\right)$} \\
\hline & 150 & 200 & 250 & Mean & 150 & 200 & 250 & Mean \\
\hline 10 & 36.75 & 38.40 & 38.00 & 37.72 & 36.10 & 36.66 & 37.24 & 36.67 \\
\hline 20 & 37.50 & 38.80 & 39.19 & 38.50 & 36.87 & 37.00 & 37.72 & 37.20 \\
\hline 30 & 38.32 & 39.10 & 39.72 & 39.05 & 37.10 & 37.23 & 38.00 & 37.44 \\
\hline LSD 0.05 & N.S & & & 0.79 & N.S & & & 0.58 \\
\hline Mean & 37.52 & 38.77 & 38.97 & & 36.69 & 36.69 & 37.65 & \\
\hline LSD 0.05 & 0.66 & & & & 0.58 & & & \\
\hline
\end{tabular}

\section{REFERENCES}

1. Akhtar, M., M.S. Cheema, M. Jamil, M.R. Farooq and M. Asiam. 2002. Effect of plant density on four statured cotton varieties. Assian J. of Plant Sci. 1 (6): 644-645.

2. Ali, H. and R. A. Hameed.2011. Growth, yield and yield components of American cotton (Gossypium hirsutum L.) as affected by cultivars and nitrogen fertilizer. International. J. of Sci. \& Engineering. Res. 2(7): 1-11.

3. Ali, A.; M. Tahir, M. Ayub, I. Ali, A. Wasaya and F. Khalid. 2009. Studies on the effect of plant spacing on the yield recently approved varieties of cotton. Pak. J. Sci. 7 (1): 25-30.

4. Barker, A. V. and D. J. Pilbeam. 2007. Handbook of Plant Nutrition. Taylor \& Francis Group. New York. PP: 613.

5. Bibi, Z., N. U. Khan, M. Mussarat, M. J. Khan, R. Ahmed, I. U. Khan and S. Shaheen. 2011. Response of Gossypium hirsutum L. genotypes to various nitrogen levels. Pak. J. Bot. 43(5): 2403-2409.

6. Boquet, D. J., E. B. Moser and G. A. Breitenbeck. 1994. Boll weight and with in plant yield distribution in field grown cotton given different levels of nitrogen. Agron. J. 86: 20-26.

7. Boquet, D.J. 2005. Cotton in ultra-narrow row spacing, plant density and nitrogen fertilizer rates. Agron. J. 97: 279-287.

8. Clawson, E.L., J.T. Cothren and D.C. Blouin. 2006. Nitrogen fertilization and yield of cotton in ultra-narrow and conventional row spacings. Agron. J. 92: 72-79.

9. Demastro, G. 1998. Influence of the irrigation timing and plant density on the cotton yield in south Italy. World Cotton
Research Conference. 2. 6-12 September. Athens, Greece: 153.

10. Fatihkilli, Y.K., A. Tufekci, O.S. Uslu and S. Karraltine. 1998. Row space X nitrogen interaction in cotton (Gossypium hirsutum L.), Turkey. World Cotton Research Conference. 2. 6-12 September. 1998. Athens, Greece: 145. 11. Feng, L., V. B. Bufon, C. I. Mills, E. Hequet, J. P. Bordovsky, W. Keeling, R. Boman and C. W. Bednarz. 2010. Effects of irrigation, cultivar and plant density on cotton within-boll fiber quality. Agron. J. 103 (2): 297-303.

12. Gormus, O. 2005. Interactive Effect of Nitrogen and Boron on Cotton Yield and Fiber Quality. Cukurova University. Faculty of Agriculture, Department of Field Crops. Adama, Turkey.PP:781.

13. Gwathmey, C. O., L. E. Steckel and J. A. Larson. 2008. Soil and skip-row spacings for irrigated and non-irrigated upland cotton. Agron. J. 100: 672-680.

14. Ibrahim, M.A.S., K.E. Ahmed, S. Osman, E.S. Ali and A.A. Hamada. 2010. Response of new cotton varieties to nitrogen fertilization in Sudan gezira. African. J. Agric. 5 (11): 12131219.

15. Khan, M.B. and J.S. Dar. 2006. Response of cotton (Gossypium hirsutum L.) cultivars to different levels of nitrogen. J. Res. Sci. 17 (4): 257-261.

16. Kumbhar, A.M., U.A. Buriro, S. Junejo, F.C. Oad, G.H. Jamro, B.A. Kumbhar and S.A. Kumbhar. 2008. Impact of different nitrogen levels on cotton growth, yield and $\mathrm{N}$ uptake planted in legume rotation. Pak. J. Bot., 40(2): 767-778. 
17. Nadeem, M.A., A. Ali, M. Tahir, M. 19. Rashidi, M and M. Gholami. 2011. Naeem, A.R. Chadhar and S. Ahmed. 2010. Effect of nitrogen levels and plant spacing on growth and yield of cotton. Pak. J. Sci. 8 (2): 121-124.

18. Ram, M and A.N. Giri. 2006. Response of newly released cotton (Gossypium hirsutum L.) varieties to plant densities and fertilizer levels. Cotton Res. J. 20 (1): 85-86.

Nitrogen and boron effects on yield and quality of cotton (Gossypium hirsutum L.). Agric \& Soil. Sci. J. 1 (4): 118-125.

20. Saleem, M.F., M.F. Bilal, M. Awais, M.Q. Shahid and S.A. Anjum. 2010. Effect of nitrogen on seed cotton yield and fiber qualities of cotton (Gossypium hirsutum L.) cultivars. Animal \& Plant. Sci. J. 20 (1): 2327. 